\title{
Meteor of illusions: the meaning of work for young public bank managers
}

\author{
ELENA BANDEIRA DA SILVA ${ }^{1}$ \\ ISABEL DE SÁ AFFONSO DA COSTA ${ }^{1}$ \\ JORGE AUGUSTO dE SÁ BRITO E FREITAS ${ }^{1}$ \\ DeNISE MedeIROS Ribeiro SALLES ${ }^{2}$
}

${ }^{1}$ Universidade Estácio de SÁ (UNESA) / MESTRAdo EM AdMINISTRAÇÃo E DESENVOLVIMENTO EMPRESARIAL, RIO DE JANEIRO - RJ, BRAZIL

${ }^{2}$ Universidade Federal Fluminense (UFF) / Programa de Pós-Graduação em Administração, Niteról - RJ, Brazil

\begin{abstract}
This article presents the results of research on the meaning of work for young managers of Brazilian public banks, guided by the social representation theory. This was a qualitative, descriptive-interpretative study. Semi-structured interviews and projective techniques of drawing and sentence completion were applied to 17 participants in the cities of Porto Alegre, Rio de Janeiro and Vitória. The process of objectification and anchoring carried out in the elaboration of the 37 social representations about the work grouped around the three dimensions: "provider and protective organization," "demanding, threatening, and profit-oriented organization," and "public organization." The representations evidenced a strong association between work and money, along with the illusory and ambiguous character of the managerial position, source of pleasure and suffering. Results suggest applicability in reviewing people management practices such as managers' involvement with workers' physical and mental health, transparency, and clarity about the roles and expectations of work within banks. The findings suggest the need for tools that respect the professionals physical, mental, and psycho-affective limits, leading to sustainable results both for workers and organizations.
\end{abstract}

Keywords: Meaning of work. Social representations. Managers. Public banks.

\section{Meteoro da ilusão: sentidos do trabalho para jovens gerentes de bancos públicos}

\section{Resumo}

Este artigo apresenta resultados de pesquisa relativa ao sentido do trabalho para os jovens gerentes de bancos públicos, norteada pela Teoria das Representações Sociais. A abordagem é qualitativa, do tipo descritivo-interpretativa. Aplicaram-se técnicas de entrevista semiestruturada, complementação de sentenças e elaboração de desenhos em 17 participantes em Porto Alegre/RS, Rio de Janeiro/RJ e Vitória/ES; explicitaram-se os processos de objetivação e ancoragem na elaboração das 37 representações sociais do trabalho identificadas, agrupadas em torno dos núcleos centrais "organização provedora e protetora", "organização cobradora, ameaçadora e com foco nos lucros" e "organização pública". Tais representações evidenciaram intensa associação entre trabalho e dinheiro, além do caráter ilusório e ambíguo do cargo, fonte de prazer e sofrimento. Os resultados sugerem aplicabilidade na revisão das práticas de gestão de pessoas, tais como envolvimento dos gerentes com a saúde física e mental dos trabalhadores, transparência dos processos, clareza sobre os papéis e as expectativas do trabalho nos bancos. O mais relevante é gerar insumos para a busca de mecanismos que favoreçam o respeito aos limites físicos, mentais e psicoafetivos dos profissionais, em busca de resultados sustentáveis para trabalhadores e organizações.

Palavras-chave: Sentido do trabalho. Representações sociais. Gerentes. Bancos públicos.

\section{Meteoro de ilusiones: significado del trabajo para jóvenes gerentes de bancos públicos}

\section{Resumen}

Este artículo presenta resultados investigativos acerca del sentido del trabajo para los jóvenes gerentes de bancos públicos, orientados por la Teoría de las Representaciones Sociales. El análisis es cualitativo, del tipo descriptivo-interpretativo. Se han aplicado técnicas de entrevista semiestructurada, complementación de frases y elaboración de diseños a 17 participantes de Porto Alegre, Rio de Janeiro y Vitória, Brasil; se han explicitado los procesos de objetivación y anclaje en la elaboración de 37 representaciones sociales de trabajo identificadas, agrupadas alrededor de los núcleos "organización proveedora y protectora", "organización controladora, amenazadora y concentrada en los lucros" y "organización pública”. Tales representaciones han evidenciado una intensa asociación trabajo-dinero, además del carácter ilusorio y ambiguo del puesto, fuente de placer y sufrimiento. Los resultados sugieren su aplicabilidad en la revisión de las prácticas de gestión de personas, tales como compromiso de los gerentes con la salud física y mental de los trabajadores, trasparencia de los procesos, claridad respecto a los roles y expectativas del trabajo en los bancos. Lo más relevante es el generar insumos para la búsqueda de mecanismos que favorezcan el respeto a los límites físicos, mentales y psicoafectivos de los profesionales, hacia resultados sostenibles para trabajadores y organizaciones.

Palabras clave: Sentido del trabajo. Representaciones sociales. Gerentes. Bancos públicos. 


\section{INTRODUCTION}

Meteors are phenomena that occur at high speed in the Earth's atmosphere as a result of the movements of the planet. By analogy, as far as height and speed are concerned, a meteoric career is one that offers the professional the opportunity of a speedy ascension. If this ascension, however, comes at the expense of one's own well-being, this success imprisons him or her and may result in illnesses, proving itself to be illusory.

Organizations are spaces where people manifest, in addition to the rationality needed to carry out their businesses, their dreams, fears and passions (ENRIQUEZ, 1997). Therefore, organizations develop from the interactions between people who are gathered together for both personal and business goals.

Banks are some of these meeting places between the individual and the collectivity. In bank branches, beliefs, values, meanings, affections and contradictions of professionals who dedicate their bodies, thoughts, emotions and energies to their working activities are developed and merged. Banks are intense environments which demand objective results, and where the performance of each employee can be controlled by means of efficient electronic systems which work in real time, in the style of the Foucaultian panoptic surveillance. Gaulejac (2014) points out that the financial market is the epicenter of capitalism today; it is the place where conflicts resulting from power relationships established by the social division of labor are revealed.

From a psychoanalytic standpoint, organizations have taken the place of other institutions such as family, church, and relationships in people's lives (FREITAS, 2002). The organization reaches the subject's unconscious, causing him to love his own difficulties and call them challenges. There is a detachment between the subject and his or hers own desires, needs and dreams, which become mixed up with the goals of the organizations. People are conditioned to enjoy belonging to that group, to that mechanism, making the daily living under tension a natural situation.

The workplace is a space for the construction of one's sense, identity and historicism (DEJOURS, ABDOUCHELI and JAYET, 2009). Studies have revealed that, for Brazilians, working remains central for the constitution of the subject (MOTA, 2012). It should be the concern of the Administration field to intensify research on the meanings of work by narrowing it down in order to approach it and, therefore, better understand it.

This article presents results of a research that aimed to explain how the meanings of work are constructed by young managers of Brazilian public banks according to their representations of working experiences - in times of rapid transformations, technological development, global intercultural exchanges and instantaneity.

Employment in public banks depends on one's approval in a public exam, which is why the dismissal of employees must be justified and preceded by specific administrative procedures. Managerial positions, however, are discretionary, so both appointment and dismissal are decided at the discretion of the upper echelons. This peculiarity of the Brazilian public sector led to the choice of managers of public banks as the subjects of the study since it was considered that job security can affect the perception of work.

For this goal, the study drawns on the Theory of Social Representations (TSR) (MOSCOVICl, 2004, 2015) as a theoretical and analytical framework. The TSR focuses on the knowledge produced by common sense in daily practices, which is constructed and reconstructed in the interrelationships between individuals and groups. Meanings are produced through language and communication in certain contexts and specific historical-cultural conditions in a holistic and dynamic structure (MARKOVÁ, 2017).

The Theory of Social Representations aligns with interpretive and critical organizational theories, and it may offer new perspectives to the description of the phenomenon under study (MARTINS-SILVA, SILVA JUNIOR, PERONI et al., 2016). Critical researchers such as Gaulejac (2014), Enriquez (2014), and Morgan (2011) defend the reflexivity of individuals as active actors in the construction of meanings out of their experiences at work, just as Moscovici, the TSR proposer, does (MOSCOVICl, 2015).

This article is divided into four sections, in addition to this introduction. In the first section, theoretical contributions related to the topic are systematized; the second section presents the research methodology adopted; the third presents the information collected through methodological triangulation and its analysis, in the light of TSR; and finally the fourth section presents the conclusions of this study. 


\section{THEORETICAL BACKGROUND}

According to the TSR, a theory proposed by Moscovici in his PhD thesis, La psychanalyse, son image et son public (MOSCOVICI [1961], 2004), individuals and groups produce and share knowledge in their daily interrelationships and experiences; these interactions result in common sense that interferes with thoughts and behaviors and is represented by images, thus enabling the interaction between reality and the world of ideas (MOSCOVICI, 2004, 2015). Jodelet (2001, p. 17) maintains that social representations are "[...] mental realities whose evidence is sensitive to us every day [...] are brought by words [...], crystallized in behaviors and in material and spacial organizations".

Social representations are elaborated through two simultaneous processes: anchoring and objectification. Anchoring allows for the interpretation and management of the environment; the subject compares something strange to a paradigm of a category that he considers appropriate and becomes familiar with it. Objectification, however, makes the abstract concrete, by reproducing a concept as an image. It is an ongoing process in which subjects incorporates or assimilates new elements when comparing them with what already exists in their own memory (ALMEIDA, SANTOS and TRINDADE, 2014; MOSCOVICI, 2015).

The representations bring together knowledge accumulated by personal experience, as well as scientific, ideological and cultural knowledge which, when shared, result in common sense that guides the actions of the group members (JODELET, 2001). Historical, cultural and societal aspects are articulated in the production of social representations, mixing subjects' beliefs, values and affections. Thus, subjects must be conceived in the concrete social context, represented by the spheres of belonging of the representations, as shown in Box 1.

Figure 1

\section{Spheres of belonging of social representations}

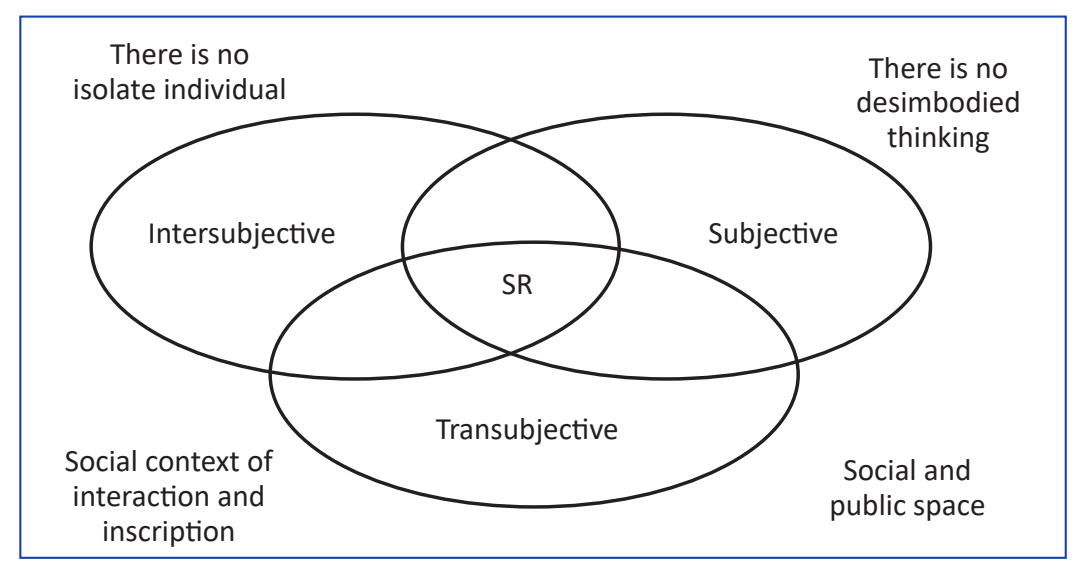

Source: Adapted from Jodelet (2009, p. 697).

The sphere of subjectivity refers to sensitivity, emotions, experiences and acquired knowledge. The sphere of intersubjectivity refers to exchanges, consensus or dissension, and shared representations. Transubjectivity, however, encompasses ideas, knowledge, values and conducts that individuals and groups have in common, including power relations and ideological aspects. The social representations belong to the intersection between these processes, whose approach must be joint and interdisciplinary (JODELET, 2009).

Social representations are organized around a "... central nucleus, a fundamental element of representation, since it is what determines its meaning and organization" (ABRIC, 2001, p. 163). This nucleus is cognitive-affective in nature and it is its most stable element. However, "the periphery is heterogeneous, and it is where circumstances transform representations" (ARRUDA, 2014, p. 449). Changes in social representation require changes in the central nucleus, which functions as an organizing principle and has a structural character. The peripheral schemes of the central nucleus absorb small disagreements with reality and end up preserving it. The permanence of the contradiction between reality and representation is what can transform it, making it change its meaning (FLAMENT, 2001). 
Having its origins in psychoanalysis, TSR makes it possible to bring to the conscious level contents which are often unconscious, through the interpretation of Freudian slips, words, discourses and conducts that reach the complexity of organizational events. When studying the social representations of workers in the oil industry whose work is carried out in isolated spaces, Salles and Costa (2013) found that they missed wearing their helmets when not at work because they lacked a frame of reference. This shows that, in routines and habits acquired in daily life, representations of work may go unnoticed.

In organizational studies there are authors who, also inspired by psychoanalysis, recognize the need for structural changes in working relations, embrace reflexivity and look critically at the relationships lived in the organizational world. They reveal the struggle for power and strength and the reduction of organizational performance to profits - reinforcing perverse and impervious personalities insensitive to feelings (GAULEJAC, 2014). Failure in achieving success generates feelings of guilt and shame because of the unsatisfactory performance that cannot match the increasingly unreachable goals (ENRIQUEZ, 2014). Thus, condemned to succeed, the subject is forced to work more and better, alienating him or herself from his or her inner reality, renouncing him or herself and losing his or her freedom to satisfy an endless ambition (MORGAN, 2011; PAGÈS, BONETTI, GAULEJAC et al., 2006).

At work, the subject confronts preexisting existential anxieties along with the restrictions imposed by the organization in which he or she is inserted (DEJOURS, 1999, 2009). At the same time, working is a source of pleasure since it enables the individual to update his or her creative and sublimatory capacity. Thus, the construction of the meaning of work is a psychosocial experience of pleasure and suffering, which can bring a psychic balance or illness. For Enriquez (2002), the positive meaning of pleasure at work is related to the possibility of performing a task, of existing, of having an identity: meaningful work is one in which the subject transforms something and, as a result, transforms himself (SILVA and COSTA, 2015).

Therefore, it is necessary to develop strategies for survival on account of work mutations, which may result in behaviors that are often alienating or even servile to the system in exchange for comfort and security (THIRY-CHERQUES, 2004). For Gaulejac (2014, p. 127), the paradox between the advantages and disadvantages of organizational life - which gives the subject autonomy while making him dependent - produces "alienation to the second power", increasing the risk of the subject starting to function in a robotic way, ceasing to produce meaning for work, going through a crisis of values, on an illusory and continuous search for something which he or she does not even know.

In the banking environment, the adoption of new productive technologies has caused the reduction of jobs, generating intense pressure that is daily experienced by the employees in the banking organizations (RESENDE and MENDES, 2004).

The history of public bank employees is marked by the administrative reform of the State, which was implemented by the Brazilian government starting in the 1990s. Aiming at results provided by the efficiency of the administrative machine, one of its objectives was to reduce the State's participation in the economic activities (1998). Large foreign institutions invested in the domestic market through mergers and acquisitions. According to Freitas (2005), in 2002, among the 50 largest Brazilian banks, 17 were already controlled by foreign hands. Dinkings (2002) reports that in March 2000 there were nine public retail banks. Today, there are five, according to data from Banco Central (2017), and only one is $100 \%$ public, the others being quasi-public corporations.

In Brazil, the financial sector is the largest investor in technology and reports show the strong growth of remote channels supported by internet or telephone, such as mobile banking, whose total number of transactions doubled each year between 2014 and 2016. Online financial transactions rose by 140\% in the period (FEBRABAN, 2017, p. 50), which proves that the bulk of bank services is being transferred from the banks to clients. The number of jobs in financial institutions is decreasing annually, from a positive balance of 34,047 in 2010 to a negative of (-) 11,486 in November 2017 (MTE / CAGED / 2018).

Investments in automated repetitive services enabled the creation of a new job position known as bank-salesperson, in charge of selling new products offered by banks such as credit cards, insurance, and bonds (JINKINGS, 2002). These professionals receive a variable payment, the amount of which is associated with individual performance, followed up on a daily basis. In addition to causing the subject to think that a job promotion depends exclusively on him, this kind of management creates a culture of competition that results in fragile interpersonal relationships and an environment full of tension, which is a source of distress, fear and suffering - the causes of which being mainly the unattainable productivity goals (BRUNO, 2011). 
Research focusing on the professional trajectories of public and private bank managers concluded that "[...] the logic of the financial system is that of pressure: pressure for results, for theoretical improvements, for constant updating, for job retention and social status, and for dedication to the company" (MÁXIMO, ARAÚJO, ZAMBRONI-DE-SOUZA et al., 2011, p. 70). The financial sector can be seen as one of the organizational environments described by Seligmann-Silva (2004) as spaces in which discomfort at work is covered and masked. Except for enthusiasm, emotions and feelings are seen as negative and, as a result, one may resort to the use of medicines, drugs, and alcohol in order to resist the psychic pressure and look well.

Due to the intense competitiveness AND pressure in the banking sector, new findings about the meaning of work for young managers of public banks may contribute to the deepening of reflections and actions inherent to the relationships of workers with their work.

\section{METHODOLOGY}

The present research used the qualitative approach, encompassing opinions and perspectives in the specific context in which individuals accumulate experiences (YIN, 2016). The interpretive-descriptive method was applied for the interpretation of the projective tests and the discourse analysis in the light of TSR. For the inductive analysis, as recommended by Creswell (2010), 17 young managers, at a maximum age of 35 years and a minimum of two years in the job position, were selected for the sake of accessibility, all of whom working in public bank branches.

The field research was carried out with three participants in Porto Alegre-RS, 10 in Rio de Janeiro-RJ, and four in Vitória-ES, in September 2017. Twenty-nine bank branches were visited as we searched for professionals who met the criteria of the study. During such visits, the study and its objectives were presented, with emphasis on aspects related to confidentiality and anonymity of participation. There was also the opportunity to do some unstructured observation of the environments, which favored the interpretation of the data.

For the investigation, the following were applied: i) projective drawing techniques (with the prompt: "What my job as a public bank manager represents to me") and sentence completion (30 sentences to be freely completed by the participant, such as "Working means ...", "The most important thing at work is ...", "I like it when I ... at work" and "I suffer when I ... at work"); ii) semi-structured interview. The drawing technique was used at the beginning of the interviews and served as a guide. The drawings were analyzed and interpreted according to Augras (1998), Silva (1981), Van Kolck (1981) and Anzieu (1978). Thus, the responsiveness, the adaptive attitude, and the acceptance of the proposal were considered. The position of the paper, the size of the drawing and the letters, the position on the sheet and even the colors they chose were observed. During the projection session, their behavior, facial expressions, occasional comments and other events were observed. After that, the graphics - proportions, strokes, position of the figure, figure and background, frame and other details were objects of observation. During the interview there was also an opportunity to talk about their drawings.

Initially we proceeded to the individual interpretation of the pieces of evidence obtained through these techniques (projection and interviews). For each participant a map of objectification and anchoring was elaborated. The presence of items repeated by different participants revealed structural patterns of their perceptions and meanings which they manifested explicitly or were implied in their discourses.

\section{ANALYSIS OF RESULTS}

Regarding the profile of the participants, 12 are married, four unmarried and one divorced. Six of them have children. As for education, all are college graduates, most of whom have a degree in Law (6) and Administration (5). Further education was pursued by 11 participants. The average working period in the bank is 10 years and in management position the average time is 6 years, but other intermediated appointed positions were taken before their promotion to management.

Next, Box 1 presents the drawings which are analyzed individually, identified by a code that informs the numerical order of the interview, from 1 to 17 ; the city of origin, being $V=$ Vitória, $P=$ Porto Alegre and $R=$ Rio de Janeiro; the gender, being identified by $\mathrm{F}=$ female and $\mathrm{M}=$ male. Then comes the age, followed by the time they had been working in the bank and, finally, the management time, both in years. Thus, for example, P1VM35, 10-6 corresponds to participant 1, from the city of Vitória-ES, male, 35-years-old, 10 years in the bank and six in management. 
Box 1

\section{Drawings and their interpretations}

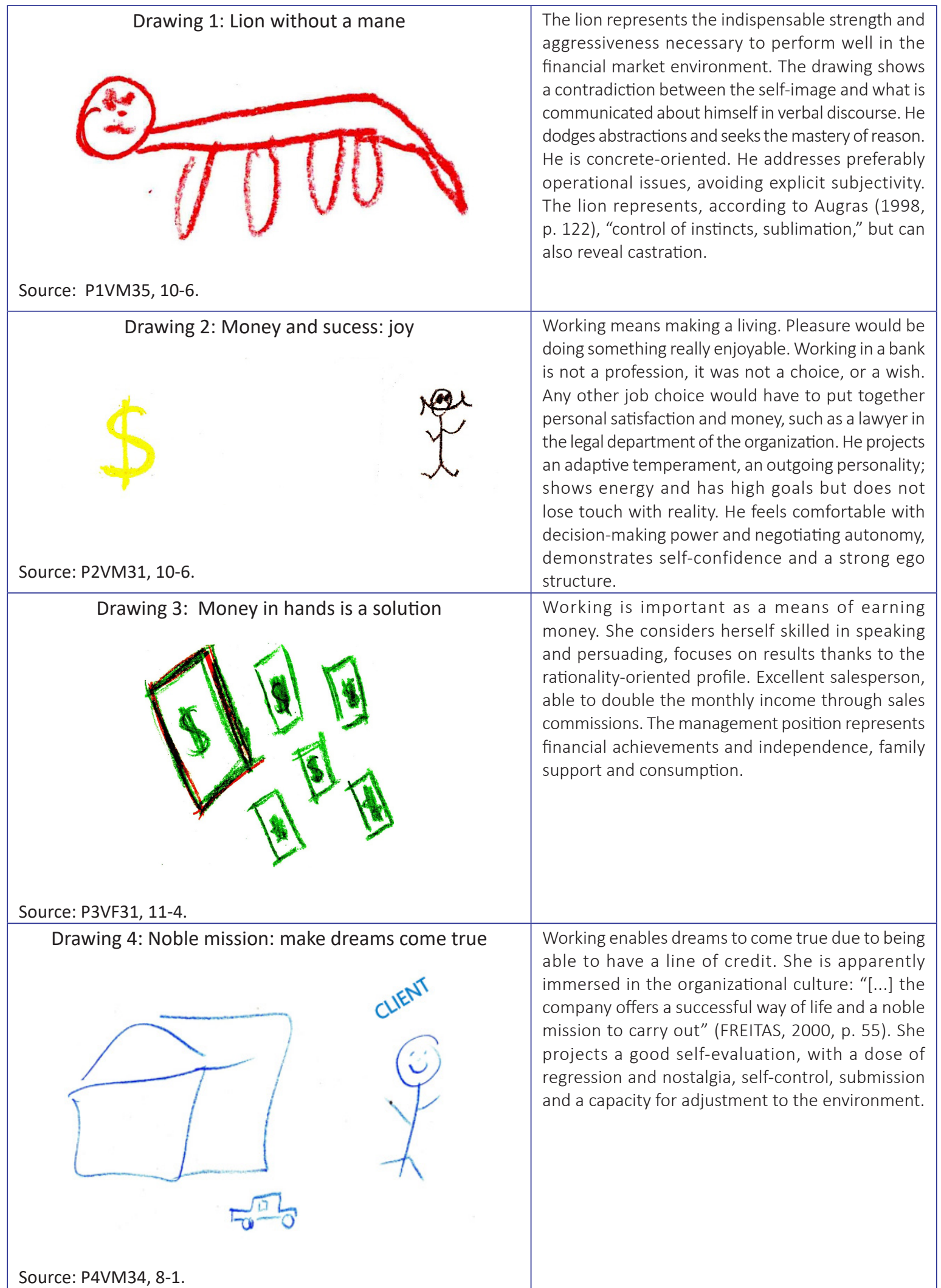




\begin{tabular}{|c|c|}
\hline SOURCE: P5RF34, 16-12. & $\begin{array}{l}\text { She was downgraded from the postition of general } \\
\text { manager as punishment for leading a strike movement } \\
\text { of managers in } 2016 \text {. She is disgusted. In the drawing } \\
\text { there are many heavy clouds: the situation is very } \\
\text { difficult. She is looking forward to the moment when } \\
\text { the sun will shine again at work. The locomotive } \\
\text { is moving, at high speed as it has to run to find } \\
\text { light. She projects poor adjustment, hostility and } \\
\text { aggressiveness towards the environment where } \\
\text { she finds repression and unresolved conflicts. She } \\
\text { displays sadness, but also self-confidence. }\end{array}$ \\
\hline IFE & $\begin{array}{l}\text { Portrays the ambiguity of the young managers' } \\
\text { careers. On one side appears the speed of career } \\
\text { advancement, on the other, how much success } \\
\text { compromises health, leisure and family time, } \\
\text { therefore being illusory. The stability offered by public } \\
\text { examination is an illusion, a "ghost" with heavy fetters. } \\
\text { Alongside much rationality appears breadth of feelings } \\
\text { and concrete intelligence, objective mentality, logic, } \\
\text { and also rational as well as spiritual development. It } \\
\text { also reveals the spontaneous temperament, being } \\
\text { noticeable the temperamental nature, the desire to } \\
\text { achieve something and to value oneself. }\end{array}$ \\
\hline SOURCE P7RF32, 7-4. & $\begin{array}{l}\text { It portrays the troubled routine of P7: she "keeps } \\
\text { moving" so that the hula hoop and the dish will } \\
\text { not fall down, despite the system that does not } \\
\text { work and the pressure exerted by the customer's } \\
\text { presence. It reveals adaptive behavior, balance, sense } \\
\text { of self-direction, strength of desires, plus altruism, } \\
\text { socialization, optimism, sense of expansion and } \\
\text { progress. It shows a certain fear of environmental } \\
\text { threats, but also vitality and constructive use of her } \\
\text { capabilities. }\end{array}$ \\
\hline $\begin{array}{l}\text { Drawing 8: Manager of the future: utilitarian } \\
\text { Source: P8RM35, 6-4. }\end{array}$ & $\begin{array}{l}\text { The managemet position is endangered; in the } \\
\text { short run all the businesses will be performed by } \\
\text { computers. But this process will not be so fast; he } \\
\text { will still be able to retire. He dreams of having his } \\
\text { management position payment incorporated into his } \\
\text { salary again and a working schedule of six hours a day. } \\
\text { The figure speaks of balance along with introversion, } \\
\text { inhibition and repression. Acuteness, precision and } \\
\text { rationality are predominant, as well as the effort to } \\
\text { control emotions. The external world is perceived } \\
\text { as uncertain and unpredictable, there is the need to } \\
\text { defend himself against dangers and to save money } \\
\text { in the event of losing his position. }\end{array}$ \\
\hline
\end{tabular}


Continue

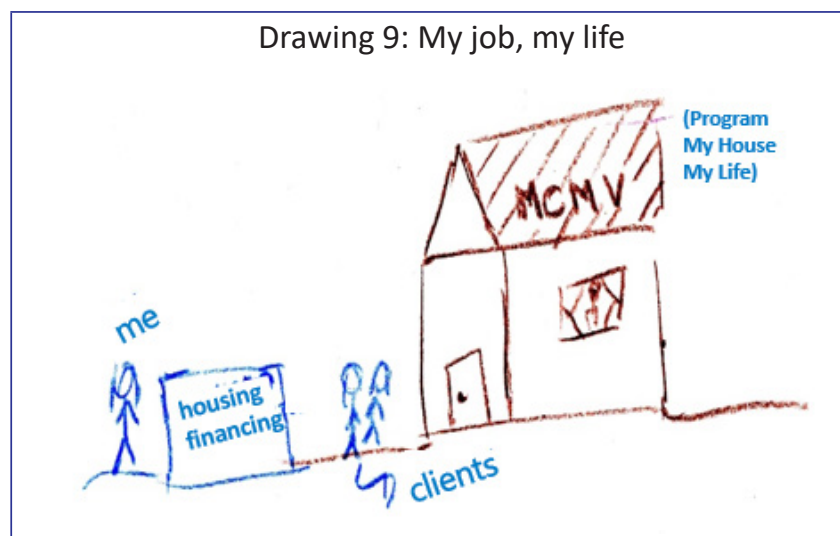

SOURCE: P9RF33, 8-2.

Drawing 10: Planting money in brazilian plantation fields

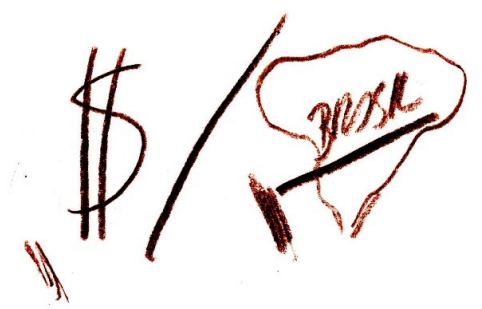

SOURCE: P10RM35,15-12.

Drawing 11: No scribbles or scratches:

i am not a public bank manager

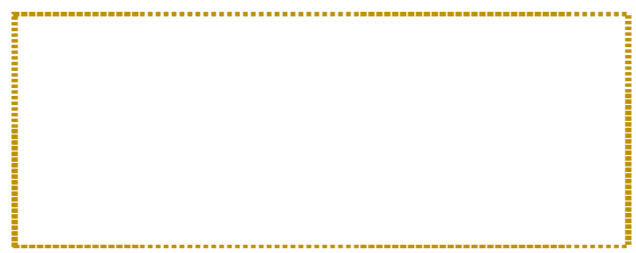

Source: P11RM34, 11-8.

Drawing 12: Masks imprisoned by the rhythm

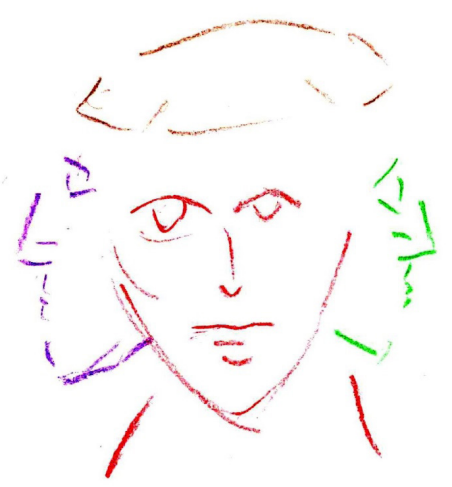

SOURCE: P12RM35, 15-5.
To explain her view about the world of work of the young public bank manager, P9 brought a "symbolic representation" (AUGRAS, 1998). This symbol emphasizes the social function of the bank, the satisfaction to make a difference toward people, the organizational mission which is transmitted from generation to generation, giving meaning to the daily working routine and showing conformity with the organizational culture. It projects an insecure, but adaptive profile, with predominance of passivity, expectation toward her life, inhibition. It also shows sensitivity, psychic endurance and perseverance.

He expresses the importance of the social function of the bank, which provides financial resources to the whole country through its activities in foreign trade and agricultural funding. Work means income. He projects passivity toward decisions that he cannot influence from the position he has currently been in, although he is affected by the restructuring of the bank. He also shows high goals, but suggests feelings of inferiority in the environment. P10 is aware that he conveys an image of power that does not correspond to reality; he states: "People think I am powerful, but I am not powerful at all".

The drawing displays a blank sheet. P11 refused to draw, arguing that he does not consider himself a public bank manager because he works with highincome clients and his reality is the same as that of private banks. Thus, P11 denies himself, unprepared to deal with the internal contradictions generated by the organization of work. On the one hand, he is objective and describes with ease the operational part of the work. On the other hand, despite the rational discourse, he had skin peeling and perceptible anxiety.

Manager of the "big retail client list", with more than 20 thousand clients, he has to deal with very different demands, and meeting all deadlines is a real race againt the clock. In fact, "[...] the temporality of work leads to the imposition of rhythm, pace, ruptures that move away from biological time, from the time of human life [...] individuals in management positions must adapt to the time of work" (GAULEJAC, 2014, p. 82). As a psychologist and a psychoanalyst, P12 projects inadequacy and rejection by the environment, but he has resources of self-worth and balance, as well as a sense of self-direction. He shows hypersensitivity, delicacy and submission, flexibility and instinctive orientation, in sharp dissonance with the environment and its daily activities. 
Continue

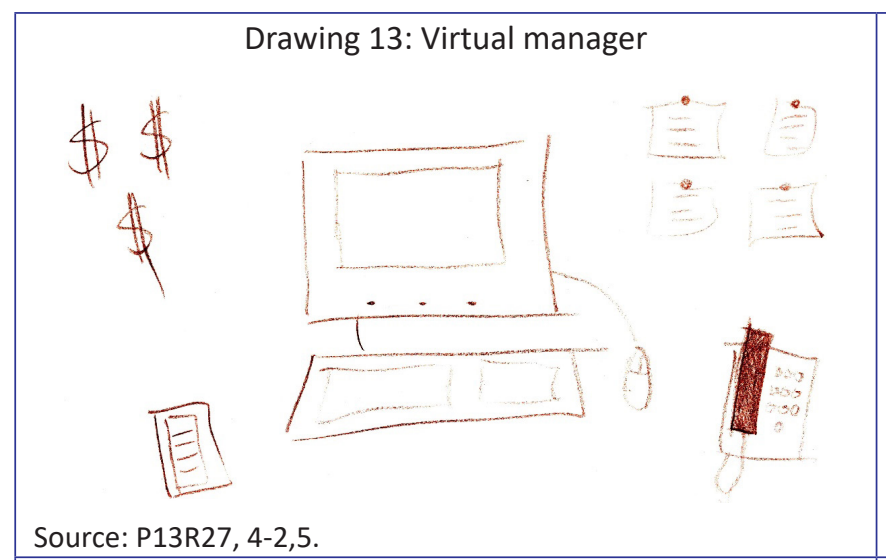

Drawing 14: Oscillant light beam

Source: P14RM29, 6-2.

Drawing 15: About everything money can buy

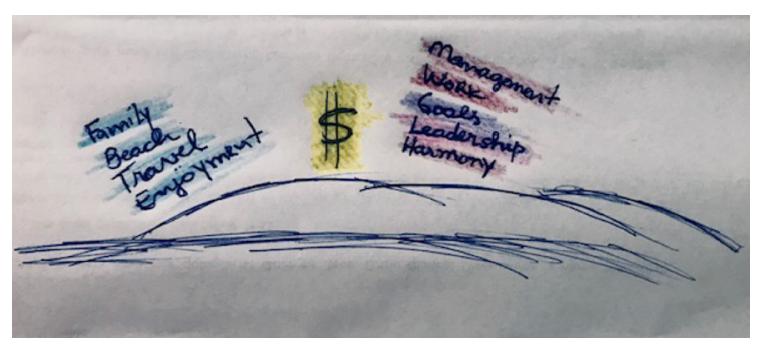

Source: P15PF31, 9-5.

Drawing 16: This side of paradise: soccer, barbecue, good chimarrão

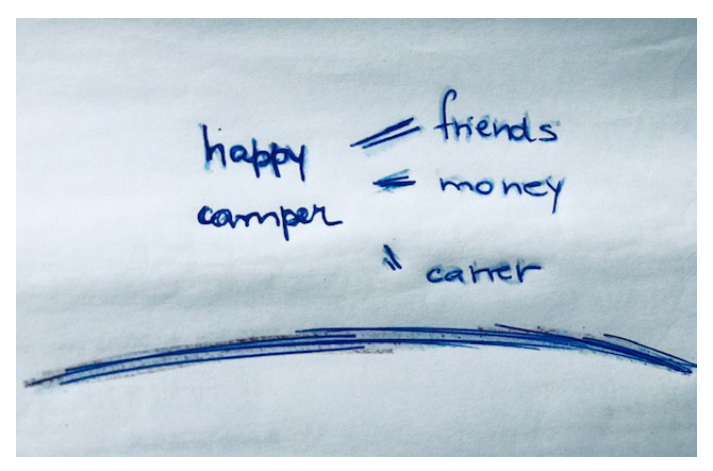

Source: P16PM35, 9-3.
Manager of the virtual office, high income segment. The scribbled post-it notes are reminders so he will not forget the multiple and immediate demands which "keep him high" all the time. Being a public bank manager is "madness." He projects openness, a sense of expansion, an attitude of expectation toward life. Shows ability to maintain personality balance, emotional perseverance, rationality. Feels good about work and expects new career growth opportunities.
The bank is very good. P14 is grateful for the organization to which he owes a lot. People may not be so good, but the bank is "a mother". He was "out of business prospects" after military service, and the bank emerged as a lifeline. Even so, he looks for "something else public [job]", calmer, smoother, more in line with the drawing, which projects the search for adaptation in the face of conflicts. He understands that "a banking job is not a profession", so he studies tirelessly for other public exams.
It is hypocritical to say that one works for personal satisfaction. P15 works to spend money, to travel, to enjoy life. Money is the defining parameter of one's choices. The projective aspects show adaptive behavior, self-worth, concrete orientation, contact with reality, control of emotions by reason and a certain obstinacy and stubbornness. After trying college entrance exams for the School of Medicine and not passing, she gave up studying Medicine and found satisfaction in the bank. Today she does not see herself doing anything else; she has prepared herself for it and she is good at what she does.

His job means "almost everything". He feels fulfilled by friends and by the financial and professional success achieved through work. What really matters is to meet friends, play soccer and enjoy a barbecue after work. He gets mad at his not-so-committed colleagues, whom he cannot dismiss and who, in his opinion, should be ashamed of being paid a better salary than what they actually deserve because of their low productivity. One might apply to him the statement that "those who do not pursue the goal of being number ones are dead weight" (GAULEJAC, 2014, p. 173). He likes hard-working people, focused on the achievement of organizational objectives, as the aristocratic golem worker, the one who makes others produce, exercises supervision and control, a "manipulated manipulator of objects, processes and other workers" (THIRY-CHERQUES, 2004, p. 37). If he could choose another career, it would be political. Affectivity is regulated by the predominance of reason. 


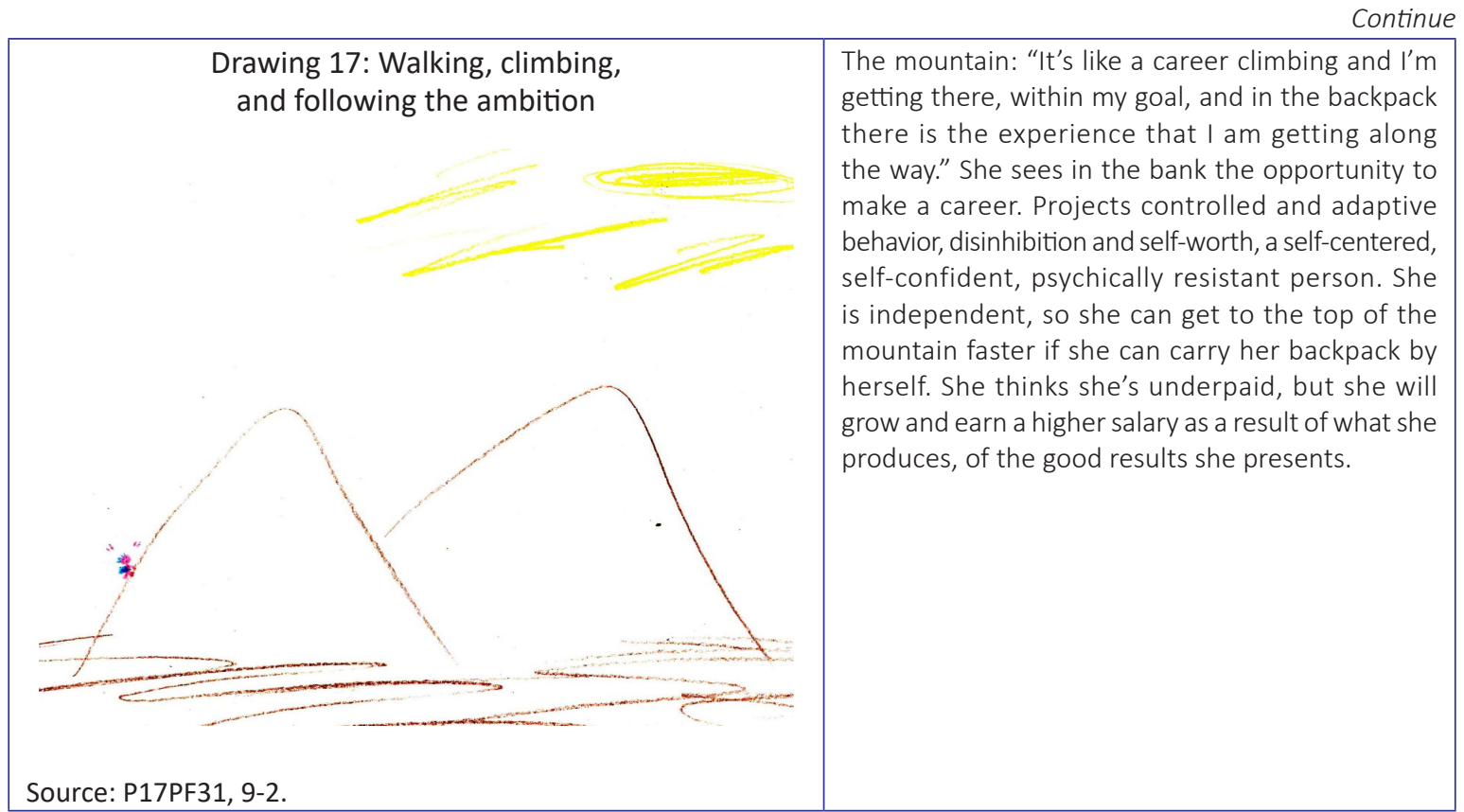

Source: Elaborated by the authors.

A reality marked by ambiguity emerges from their discourses because the organization, in its implacable search for financial results, provides and protects at the same time that it threatens and punishes. The balance is either bent toward satisfaction with wages, with the power of consumption and success, or toward meeting goals and demands, without the necessary conditions for their fulfillment. Rapid promotion is counterbalanced by the risk of losing the managerial position, in a way similar to the contradiction between imprisonment and freedom that Salles and Costa (2013) have identified in representations of confined workers. The young managers achieve financial autonomy, but they are imprisoned by their own ambition since they need to work more and more to maintain their managerial position (MORGAN, 2011; ENRIQUEZ, 2014).

Young managers seek adaptive ways to face reality since the production of meanings of work is crossed by contradictions, superficiality and alienation in relation to the facts. They defend their love for the organization and blame higher managers or the government for their problems, as a defensive strategy in the face of representations of negative connotation. For these managers, the perception of work becomes objectified and comprehensible, politically and ideologically framed, according to the characteristics of the environment and the socio-cultural background of each participant and the group - creating a common sense about the experience of being a manager in a public bank.

Some advocate the private model, which allows for the dismissal of colleagues who are not subject to the unbridled pursuit of financial results. They are close to the profile that Enriquez $(2002$, p. 17) identifies as a technocrat, for whom "[...] workers are seen only through their current economic value, because the technocrat does not perceive anything in the world other than what brings to him incresingly profitable business exchanges".

The desires for change, modernization and streamlining of processes, reduction of political interference, and the implementation of meritocracy coexist with the fear of losing their current status.

Moscovici (2015, p. 61) argues that "[...] things that are not classified and have no name are strange, non-existent and at the same time threatening." Anchoring and objectification allow for the classification of each event by giving it a name, thus making it a concrete reality integrated with thought. The personal stories told by the participants provided elements that enable them to understand the values and beliefs they have been taught and are brought to the present moment by mnemonic processes and communication.

There are persistent patterns that reveal consensus and confluence of opinions among the participants, even circumstantial ones, which allow for the arrangement of a joint interpretation, as suggested by Yin (2016). Thus, Box 2 describes the processes of elaboration and identification of the social representations of work of the young managers. Elements of the speeches that 
reveal what anchors $(\mathrm{A})$ each of the 37 representations, as well as the ideas and concepts in which they are objectified (O), according to TSR, have been listed from the interviews and sentence completion.

\section{Box 2}

\section{Process of anchoring and objectification of social representations}

\begin{tabular}{|c|c|c|}
\hline \multicolumn{2}{|r|}{ Anchoring (discourse element) } & \multirow{2}{*}{$\begin{array}{l}\text { Objectification } \\
\text { (ideas/concepts) } \\
\text { Good salary } \\
\text { and benefits }\end{array}$} \\
\hline $\mathrm{AO} 1$ & $\begin{array}{l}\text { Salary is important; my salary today, my stability, is much better than that of my colleagues } \\
\text { who graduated with me; the organization pays the 13th and 14th salaries, has a profit-sharing } \\
\text { plan, health insurance, good meal tickets; my friends' salaries are lower; working means } \\
\text { only earning money; the products pay well; I work here only because I depend on this job } \\
\text { to pay my bills; the manager's salary is well above the average in the market; I came from } \\
\text { two other public jobs which paid much lower salaries; salary is the most important thing; } \\
\text { working is a way to maintain a nice life standard, enjoy leisure; I work for the money, I think } \\
\text { it's hypocritical to say that one works because he likes it; I work because I am paid for that, } \\
\text { otherwise I would stay home watching TV. }\end{array}$ & \\
\hline $\mathrm{AO} 2$ & $\begin{array}{l}\text { I was promoted very fast; there is the opportunity to make a career; as soon as I graduated } \\
\text { from college, I became a manager, and two years later, a general manager; in six months I } \\
\text { became an assistant and already earned more than I did as a lawyer; I used to be a psychologist } \\
\text { in a surveillance company where there was no possibility of growing; in three years I became } \\
\text { customer service manager, and then relationship manager, and then went to the high income } \\
\text { department, manager of administration and now general manager; my ascension was very } \\
\text { fast, meteoric, the old folks took a lot longer to move on to higher functions. }\end{array}$ & $\begin{array}{c}\text { Rapid } \\
\text { progression }\end{array}$ \\
\hline $\mathrm{AO} 3$ & $\begin{array}{l}\text { Daily relationship with colleagues is important; clients wait two, three hours to talk to me, } \\
\text { they trust me; I have made friends here in the bank; some of the good parts are my peers; } \\
\text { the best thing about my job is the contact with people; I have a friend from the bank who was } \\
\text { my best man; the best thing in the bank for me are my friends; I feel fullfilled around people. }\end{array}$ & $\begin{array}{l}\text { Interpersonal } \\
\text { relationships }\end{array}$ \\
\hline $\mathrm{AO} 4$ & $\begin{array}{l}\text { Public exams give you more security; not stability, we are under private labor laws; here the } \\
\text { pay is steady, but not outside; I used to have a journalism company, it's very difficult to deal } \\
\text { with employees; I am afraid of losing what I have achieved and having to go through what I } \\
\text { had to endure in my childhood and teen years again; I still see the bank, because it is public, } \\
\text { as a more stable employment than the ones in the private market; working means security; } \\
\text { my mother had a private school, and a business partner; we experienced the difficulty of } \\
\text { maintaining a company in this country; knowing that every 25th of the month you will receive } \\
\text { your paycheck gives you peace of mind. }\end{array}$ & $\begin{array}{l}\text { Stability and } \\
\text { security }\end{array}$ \\
\hline $\mathrm{AO5}$ & $\begin{array}{l}\text { What motivates me is the achievement; you are getting better and better every day; my job } \\
\text { represents pride and satisfaction; I am considered one of the best salesperson in the bank; I } \\
\text { don't find it difficult to meet the goals; I'm fine with my job; I'm in a good position. }\end{array}$ & Success \\
\hline AO6 & $\begin{array}{l}\text { The organization and I have a love affair (with many misunderstandings); I am very grateful } \\
\text { for everything I have achieved by working for this company; the company and I understand } \\
\text { each other; I am thankful for having a good job; I see my colleagues who have a degree, } \\
\text { experience and do not have a good job; the company is excellent, like a mother; people may } \\
\text { not be nice, but the bank is very good, I owe a lot to this bank; I love the bank and I love it } \\
\text { even when I hate it. }\end{array}$ & Love and gratitude \\
\hline $\mathrm{AO7}$ & $\begin{array}{l}\text { The routine is very dynamic, no two days are the same; I like to learn a lot from people... it } \\
\text { sounds like jargon, but I can absorb and learn in any situation; It's a new experience every } \\
\text { day, it makes you grow mature. }\end{array}$ & Learning \\
\hline $\mathrm{AO8}$ & $\begin{array}{l}\text { We pay civil servants; we do tax collection; I have always liked housing/mortgage department; } \\
\text { it is good to see clients happy, helping their dreams come true; my work means money that } \\
\text { the bank moves in the country, for agriculture, for foreign trade; meaningful work? I have to } \\
\text { see if I'm making a difference in the community; working should mean doing something that } \\
\text { helps building something socially. }\end{array}$ & Social function \\
\hline $\mathrm{AO9}$ & $\begin{array}{l}\text { The point is security, financial security, getting older and not worrying about money; I see } \\
\text { myself retired in the bank, I am not an entrepreneur; at the moment I fear a tight retirement; } \\
\text { I attend to Social Security pensionists and I know that the income goes down further ahead } \\
\text { after retirement. }\end{array}$ & $\begin{array}{l}\text { Financially secure } \\
\text { retirement }\end{array}$ \\
\hline
\end{tabular}


Continue

\begin{tabular}{|c|c|c|}
\hline \multicolumn{2}{|r|}{ Anchoring (discourse element) } & \multirow{2}{*}{$\begin{array}{c}\begin{array}{c}\text { Objectification } \\
\text { (ideas/concepts) }\end{array} \\
\text { Financial } \\
\text { independence; } \\
\text { Support }\end{array}$} \\
\hline $\mathrm{AO} 10$ & $\begin{array}{l}\text { Working is something imposed, the system requires me to work to support myself, have a } \\
\text { good job and not depend on third parties financially; working means to provide support for } \\
\text { myself and my family. }\end{array}$ & \\
\hline A011 & $\begin{array}{l}\text { I deal directly with the partners of the company; I did not have the intention to become a } \\
\text { general manager, but now I started to change. }\end{array}$ & Power \\
\hline $\mathrm{AO} 12$ & $\begin{array}{l}\text { Peers: we try to team up and work together; it is easier to achieve the goals when we work } \\
\text { together. }\end{array}$ & Teamwork \\
\hline $\mathrm{AO} 13$ & $\begin{array}{l}\text { Portfolio demands a target; the branch has a target; enrollment has a target; the company only } \\
\text { seeks profit, sees us as numbers; we have lived with campaigns, weekly challenges, dynamic } \\
\text { goals; if I had to choose another job it would be a public one, but without goals, without } \\
\text { so many demands; every day is the "most important day of the month", the results are not } \\
\text { cumulative; you don't breathe; I don't identify myself much with the manager's job, with } \\
\text { the goals, the type of demands; we have targets for products, for turnover, for expenses, for } \\
\text { charging, for default on payments, for the management of the branch, and for the portfolio. }\end{array}$ & $\begin{array}{l}\text { Goals, } \\
\text { demands }\end{array}$ \\
\hline $\mathrm{AO} 14$ & $\begin{array}{l}\text { Some days we do not even sleep; there are many people on sick leave for psychological } \\
\text { problems; we can not forget work when we get home; my health tests and treatment... are } \\
\text { put aside... I'm sick, I suffer a lot, I feel sick, I get headaches, I get nervous and have pain } \\
\text { everywhere; when I go on vacation, everything is fine; after I started in the bank, my agitation } \\
\text { increased greatly, today I am hyperactive; I have headaches, sometimes if you are stressed } \\
\text { out, right, you're somatizing; I had high blood pressure, I had difficulties at work, I put on a } \\
\text { lot of weight and weighed } 141 \text { kilos; it is a way of escaping; you have to do something, some } \\
\text { drink, others eat emotionally; I am the type who eats; I did not have a routine; I kept working } \\
\text { without stopping for lunch; I need time for physical exercises, I can't lose the } 30 \text { kilos I have } \\
\text { put on after starting working in the bank; I have shortness of breath, sedentary lifestyle brings } \\
\text { consequences... circulation... varicose veins, swelling, fluid retention, migraine, headache, } \\
\text { pain on the shoulders, pain in the hands, tired eyes... it is getting worse ..... }\end{array}$ & $\begin{array}{l}\text { Poor } \\
\text { health }\end{array}$ \\
\hline $\mathrm{AO} 15$ & $\begin{array}{l}\text { Today I do not know what I would do if I lost my job, the salary would fall from } 13 \text { to } 3 \text { thousand } \\
\text { reais; I avoid going into long-term debt; losing the position greatly reduces the salary, the } \\
\text { relationship manager earns } 8 \text { thousand reais; it goes down to } 4 \text {; I came to this branch fearing } \\
\text { losing the commission due to the restructuring; it is a bargaining tool; if you do not hit the } \\
\text { target, tomorrow you may not be on this commission; if you get three bad evaluations you } \\
\text { can lose this commission; the greater part of the salary is the commission, if I lose it, I will } \\
\text { earn less than half of my present salary. }\end{array}$ & $\begin{array}{l}\text { Fear of losing } \\
\text { the management } \\
\text { position payment }\end{array}$ \\
\hline A016 & $\begin{array}{l}\text { The more you sell, the more work you have; my routine is stressful, it's me and myself; now } \\
\text { no one else has extra support; they dismissed the people who used to help us; those who } \\
\text { work in the branches are overworked. }\end{array}$ & $\begin{array}{l}\text { Lack of a support } \\
\text { team }\end{array}$ \\
\hline $\mathrm{AO} 17$ & $\begin{array}{l}\text { You get a lot of everything ... a lot of pressure; the other day I could not talk to clients because } \\
\text { of lack of time; there were complaints; short deadlines, everything is mixed with anxiety, } \\
\text { with agony, everything is a huge problem; there are many tasks, tasks that are "doable", but } \\
\text { not within the time frame set by the bank; working in a bank is a rush, not momentarily but } \\
\text { all the time. }\end{array}$ & $\begin{array}{c}\text { Short } \\
\text { deadlines }\end{array}$ \\
\hline $\mathrm{AO} 18$ & $\begin{array}{l}\text { I have } 900 \text { clients that demand a lot from me; and still receive email and WhatsApp messages } \\
\text { from clients; too much work at the same time, people interrupting you all the time, I can't finish } \\
\text { a single process and it feels like I'm in a marathon from the time I arrive until the time I leave. }\end{array}$ & $\begin{array}{l}\text { Multiple } \\
\text { demands }\end{array}$ \\
\hline AO19 & $\begin{array}{l}\text { The company is going through a very long restructuring process; branches are going out of } \\
\text { business, managerial functions are disappearing, we do not know what will happen; the } \\
\text { number of managers has shrunk with the restructurings. }\end{array}$ & Restructuring \\
\hline $\mathrm{AO} 20$ & $\begin{array}{l}\text { I am afraid of losing my job; I am afraid of being unemployed manager; we adapt ourselves, } \\
\text { but the job... there are many ex-bank employees driving taxis in Rio. }\end{array}$ & $\begin{array}{l}\text { Fear of losing } \\
\text { the job }\end{array}$ \\
\hline $\mathrm{AO} 21$ & $\begin{array}{l}\text { I can't do anything else, I start at 9am and leave at } 6 \mathrm{pm} \text {; I came to the bank because it was } \\
\text { a 6-hour working day; I had the illusion that I could work } 6 \text { hours a day. }\end{array}$ & $\begin{array}{l}8 \text { hour-working } \\
\text { day }\end{array}$ \\
\hline $\mathrm{AO} 22$ & $\begin{array}{l}\text { The incorporation is practically prohibited; we no longer have a management position payment } \\
\text { incorporation, I worry because a person who has been a manager for } 20 \text { years, either he } \\
\text { stops working or dies. }\end{array}$ & $\begin{array}{l}\text { Fear of losing the } \\
\text { managent position }\end{array}$ \\
\hline
\end{tabular}


Continue

\begin{tabular}{|c|c|c|}
\hline \multicolumn{2}{|r|}{ Anchoring (discourse element) } & \multirow{2}{*}{$\begin{array}{c}\begin{array}{c}\text { Objectification } \\
\text { (ideas/concepts) }\end{array} \\
\text { Downgrading } \\
\end{array}$} \\
\hline $\mathrm{AO} 23$ & I was downgraded because I led a striking movement of managers. & \\
\hline $\mathrm{AO} 24$ & $\begin{array}{l}\text { If you are demoted and sent to a smaller branch, the general manager's salary goes down } \\
\text { too, depending on the branch rank; managers of business accounts who do not have } 300 \\
\text { clients on the portfolio are downgraded. }\end{array}$ & Demotion \\
\hline AO25 & $\begin{array}{l}\text { You have to be productive and there is another person who wants your place; you have to } \\
\text { sell the whole line of life, car, residence insurance, consortium ...I do not know how they do } \\
\text { that, really I don't know; If I did, I would do the same. }\end{array}$ & $\begin{array}{l}\text { Internal } \\
\text { competition }\end{array}$ \\
\hline $\mathrm{AO} 26$ & $\begin{array}{l}\text { There may be hiring of temp workers, including branch managers; portfolio managers can } \\
\text { be outsourced. }\end{array}$ & Outsourcing \\
\hline $\mathrm{AO} 27$ & $\begin{array}{l}\text { I've been mugged, gun in my head, that thing; I am afraid of violence, in relation to security, } \\
\text { robbery. }\end{array}$ & Robbery \\
\hline $\mathrm{AO} 28$ & $\begin{array}{l}\text { I knew that to have a good job, I would have to study hard, I did not want to have bad jobs } \\
\text { like my brothers' and my father's; my father wanted me to be a lawyer, to word for the labor } \\
\text { court; we often think that we are in prison because ... the ghost of the public exams, we } \\
\text { are afraid to let go; I sat } 14 \text { public exams; I passed this one; my mother signed me up for the } \\
\text { exams; my parents are retired employees; I would like to be somewhere else, but somewhere } \\
\text { in the public area; my father worked for Banco do Brasil; my father was a civil servant, so since } \\
\text { I was little I have always heard that stability for life came from public exams; my mother is a } \\
\text { civil servant and she has always encouraged me to sit public exams. }\end{array}$ & Public exams \\
\hline AO29 & $\begin{array}{l}\text { "Enter that operation now because the director is demanding it!"; the long-term political } \\
\text { scenario... I see no future for the company; the government, it is intentionally scrapping the } \\
\text { company; the worst of my job is the volatility brought by government politicians. }\end{array}$ & $\begin{array}{l}\text { Political } \\
\text { interference }\end{array}$ \\
\hline $\mathrm{AO} 30$ & $\begin{array}{l}\text { Some colleagues lack motivation; people lack focus on results; there are too many lazy people, } \\
\text { who are friends with somebody in higher ranks; our staff is lazy and uncommitted; that is, } \\
\text { they are just waiting for retirement; I do not like the posture of just demanding rights and } \\
\text { having no duties in return. }\end{array}$ & $\begin{array}{l}\text { Lack of } \\
\text { commitment }\end{array}$ \\
\hline AO31 & $\begin{array}{l}\text { There is no selection process for general manager; it is by appointment; you see people who } \\
\text { are less capable than you being appointed to the position; the governor chooses technical } \\
\text { managers to manage the bank; there are terrible managers who do not even know what our } \\
\text { performance index is made of. }\end{array}$ & $\begin{array}{l}\text { Political } \\
\text { appointments }\end{array}$ \\
\hline $\mathrm{AO} 32$ & $\begin{array}{l}\text { I materialize the public bank in the restraints, in the bidding, in the red tape; if I want to paint } \\
\text { the wall I have to go through a bidding, it takes more than a year; red tape, agreements, } \\
\text { legal issues. }\end{array}$ & Red tape \\
\hline $\mathrm{AO} 33$ & $\begin{array}{l}\text { There is no punishment; the bank is not strict, on the contrary, the bank is very benevolent; } \\
\text { the big problem of our bank: the fact that hiring is done through public exams; sometimes } \\
\text { we can't demand anything from anyone and the bank can't fire anyone. }\end{array}$ & Impunity \\
\hline $\mathrm{AO} 34$ & $\begin{array}{l}\text { Privatization is something that makes me afraid today; in case of privatization, of course there } \\
\text { will be dismissals, but not all will be fired; the bank has } 12,000 \text { employees and I am sure I will } \\
\text { stay among the } 3 \text { thousand that will be kept; my résumé and my performance make me feel } \\
\text { safe; privatization does not worry me; privatization is the natural way. }\end{array}$ & Privatization \\
\hline $\mathrm{AO} 35$ & For me, that's fine, the professionals who work well, who bring good results, will have a space. & Meritocracy \\
\hline AO36 & $\begin{array}{l}\text { The lack of corporate governance, lack of transparency and criteria for promotions / dismissals } \\
\text { and the hypocrisy of superiors; it's a wonderful place to work, the problem is those who are } \\
\text { in control today; I miss having a tutor, a mentor; you have to do what you are told to do. }\end{array}$ & $\begin{array}{l}\text { Lack of reliable } \\
\text { inspiring } \\
\text { leadership }\end{array}$ \\
\hline AO37 & $\begin{array}{l}\text { My main problem here is the lack of technological structure; do the systems work? No, that } \\
\text { doesn't change; we don't have the structure to be a manager; we do not have the technology } \\
\text { nor the qualified workforce; the system doesn't always work as we wish. }\end{array}$ & $\begin{array}{l}\text { Inadequate } \\
\text { technology }\end{array}$ \\
\hline
\end{tabular}

Source: Research data. 
Thus, in the structure of social representations of the young managers, three central nuclei of different connotations emerged: positive connotation, "providing and protective organization" (AO1 to AO12); negative connotation, "demanding, punitive, profit-oriented organization" (AO13 to AO27), and a variable connotation (either as positive or negative connotation, depending on the circumstance), "public organization" (AO28-AO37). They are rigid dimensions of the representations (central nuclei) around which the peripheral constituent elements have been organized and grouped by symbolic affinity.

Figure 2 shows the representations of the group studied. The number inside the gears tells how many participants referenced that representation. It shows how the perceptions of life and work are engendered in the mode of a system, a moving gear, in which the social representations of the group are continuously (re)elaborated, resulting from continuous anchoring and objectification processes, influenced by individual experiences as well as by experiences of the social and organizational culture.

Figure 2

\section{Social representations of work of young managers of public banks}

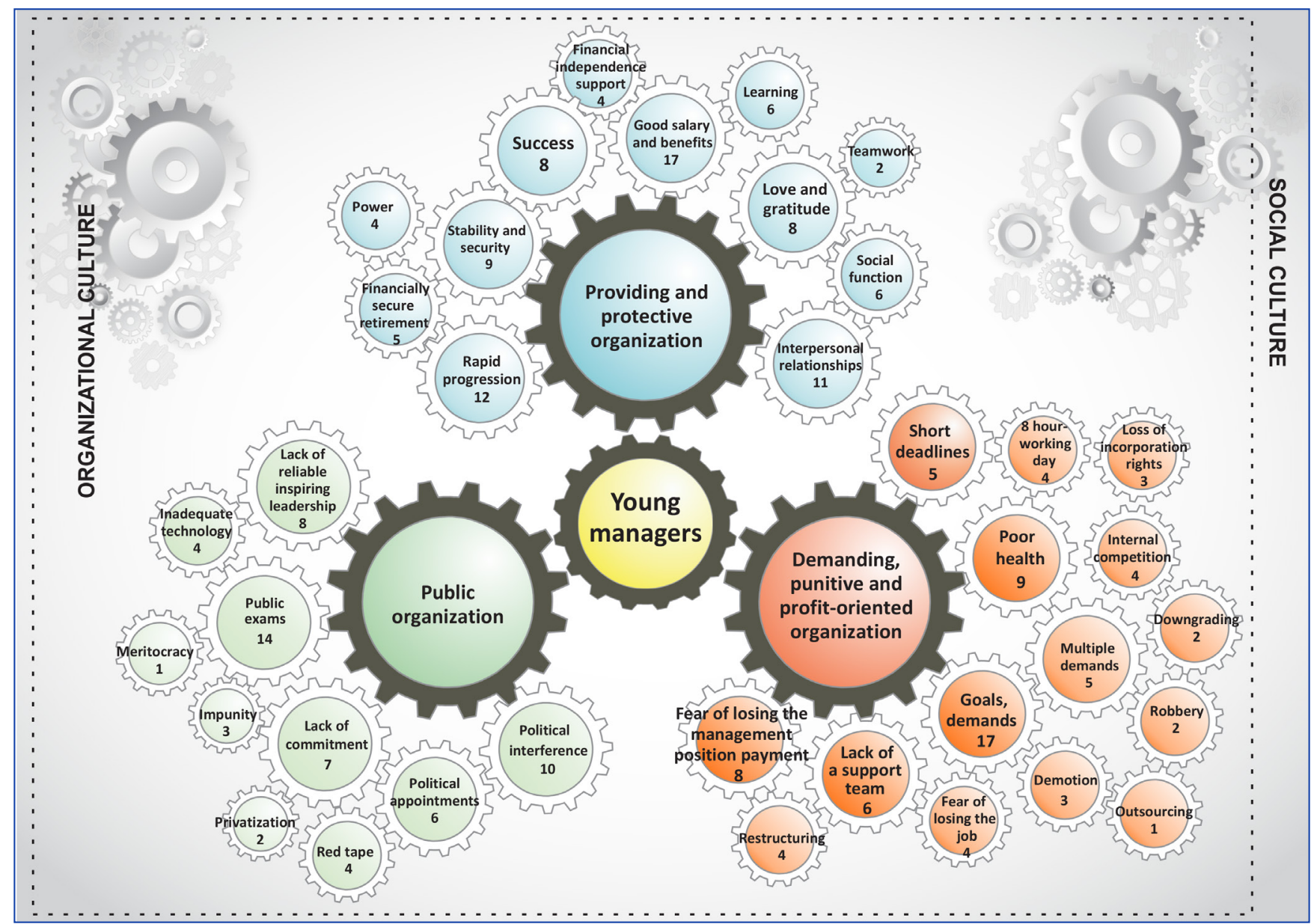

Source: Elaborated by the authors.

It may be observed that the work predominantly assumes a functional and instrumental meaning for these young people, incorporating a positive connotation when it provides the means necessary for survival, as well as comfort and leisure, represented by "good salary and benefits." This representation holds the characteristic of unanimity, evidencing that, above all, it is compensation what moves young managers.

At the same time, the job is tiring, assuming a negative connotation regarding the conditions for going about the tasks. The demand for goals and results is another representation that appears with unanimity among young managers, appearing as a source of ills that afflict them, with an impact on their health. However, the feelings of love, gratitude and admiration for the organization are strong enough to counteract negative thoughts and feelings in the face of unpleasant events. 
On a daily basis, as they belong to the intermediate managerial ranks, they are not involved in strategic decisions, which are made in higher echelons, following the traditional top-down model. Therefore, it is up to them to conform to the norms, constructing an image in accordance with the requirements, in order to remain fit for the position in an environment of great competition, fear of loss of management positions, and insecurity about the future. Downgrading means the risk of feeling incompetent, unsuccessful, and losing the condition of belonging, as well as impairing their image in front of colleagues, relatives, acquaintances and themselves.

In general, the participants were born in working class families, the children of workers, farmers, some civil servants and even employees of public banks. At the expense of self-fulfillment and good health - the downside of which appears in reports of obesity, stained and peeling skin, spinal problems, pain in the hands, shoulders and negative emotions - they remain in the comfort zone offered in the golden cage, represented by good salary, benefits, security and stability. All this reveals the increasingly intense use of their mental, emotional, and physical force for the sake of ambition and career success - as described in Morgan's metaphor of the psychic prison (MORGAN, 2011).

Although they say that the best thing at work is contact with people, individualism is the rule. The objectives are individualized, promoting the fragmentation of affective bonds. It was revealed that these young people adhere to the managerial discourse and are in agreement with the model of management by results in the public companies to the detriment of their social function. There is a consensus on the need to generate profits because they believe that this is the reason why organizations exist and that is the purpose of their positions they hold.

The banks do not appear as places for the manifestation of emotions. Dissatisfaction, sadness and boredom generate distrust about the productive capacity of individuals. Therefore, in general, the young managers are reserved and try to convey an image of tranquility. Resisting pressure with balance and serenity is a prerequisite for maintaining credibility before clients and bosses: this behavior is indicative of the most suitable candidate for promotions. In this sense, it has also been found here that young managers should look well, display cheerfulness and willingness in order to hide their psychic suffering.

What emanates from the evidence is an "opaque" feeling, devoid of genuine joy and enthusiasm towards work. The feelings and perceptions of the young managers are distorted and the technocratic artificialism of the financial environment somehow makes them alienated and distant from themselves as they follow the flow of their working routine. By repressing their emotions and naturalizing the pursuit of consumer pleasures, they are distressed by the fear of the loss of stability they may not even have.

It is not a question of adopting a uniform approach towards young managers, since there are people who do not conform to the imposed scheme. However, they have very few opportunities to release repressed conflicts: survival is an imposition and the secondary gains are attractive. There is also a limit from which point the person begins to react: when the central nucleus of the providing and protective company is shaken, they find the stimulus for questioning. It would be necessary to look at the situation from the outside, dissect it, analyze it, and reinterpret reality without any illusions or utopias in order to understand the symbolic dimension that permeates it and, with that, run the risk of destabilizing the rules.

Expectations are favored to the detriment of evidences. These young managers believe that by their merit they will be spared during difficult times the banks may face. Although changes such as the virtual bank, for example, are already in operation, in their imagination there will always be the need of people, and the good employees have their places guaranteed. Despite the false judgement pointed out by Thiry-Cherques (2004), in moments of crisis and adverse conditions, reflexivity awakens and forces a critical look at reality, causing anguish and suffering, but also the power to overcome them. The individual becomes more and more vulnerable in the face of the organization, but he or she has a reflective and deliberative capacity to "think about the world, [...] question him or herself and the environment, [...] and may think of something different from what exists ... “(GAULEJAC, 2014, p. 293). 


\section{CONCLUSION}

Many young people are looking for a job that is meaningful and safe to start their professional journey. However, technological, legal and economic changes show that traditional stability is becoming a dream. In the current situation, the prognosis is the reduction of the number of jobs available in public banks. Being in a management position that can be lost shows that success is illusory, either by the price to be paid or because it may be ephemeral - aspects found in the speeches and drawings of the participants in this study - and was represented and verbalized by one of the participants in this study as the "meteor of illusions".

The results of this research on the meaning of work for young bank managers confirm, unanimously, the association between work and money. Also, interpersonal relationships emerge as an important social representation of work among these managers and they can be stronger if cooperation is stimulated.

There is no finitude for the search of the meanings of work and for the elaboration of new representations. The process is dynamic, and the representations presented here are linked to a particular group, with specific sociocultural characteristics and in a specific scenario, so these results should not be generalized. On the contrary, due to the limitations and restrictions of this study, inquiries on the subject have increased and new and complementary investigations are important. In special, it would be recommended to extend this study to other units / locations and involve a larger number of young managers, as well as extend it to other professions, in addition to a longitudinal study with the same participants.

For a possible appropriation of the results of this research by the organizational practice, we have highlighted aspects of the representations linked to the central nucleus "demanding, punitive, profit-oriented organization", whose peripheral scheme allows for relatively simple and direct actions. In this sense, the reduction of stressing factors, whether internal to the subject or external, that is, contextual, can be, to a certain extent, achieved by management, through preventive or interventional actions regarding the physical, mental and psycho-affective limits of individuals. It is up to managers to consider the link between health and work, mediating this relationship, involving everyone in the understanding of the situation and in the unfolding of the managerial function. From this point, it is possible to lead working processes to the successful achievement of sustainable results, delivering quality services that can foster employee engagement and customer loyalty.

Last but not least, important changes may involve political action and take longer to be implemented, but any step further towards understanding the role of work will be important to render working life better for human beings. 


\section{REFERENCES}

ABRIC, J. C. O estudo experimental das representações sociais. In: JODELET, D. (Org.). As representações sociais. Rio de Janeiro: UERJ, 2001. p. 154-172.

ALMEIDA, A.M.O; SANTOS, M.F.S; TRINDADE, Z.A. Teoria das Representações Sociais: 50 anos. Brasília: Technopolitik, 2014.

ANZIEU, D. Os métodos projetivos. Rio de Janeiro: Campus, 1978.

ARRUDA, A. Representações sociais: dinâmicas e redes. In: ALMEIDA, A. M. O.; SANTOS, M. F. S; TRINDADE, Z. A. Teoria das Representações Sociais: 50 anos. Brasília: Technopolitik, 2014, p. 442-491.

AUGRAS, M. A dimensão simbólica: o simbolismo nos testes psicológicos. 3. ed. Petrópolis: Vozes, 1998.

BRESSER-PEREIRA, L. C. Gestão do setor público: estratégia e estrutura para um novo Estado. In: BRESSER-PEREIRA, L. C.; SPINK, P. (Orgs.). Reforma do Estado e administração pública gerencial. Rio de Janeiro: FGV, 1998.

BRUNO, W. P. Bancários não são máquinas. In: SZNELWAR, L. (Org.). Saúde dos bancários. São Paulo: Publisher, 2011. p. 21-32.

CRESWELL, J. W. Projeto de pesquisa: métodos qualitativo, quantitativo e misto. 3. ed. Porto Alegre: Bookman Artmed, 2010.

DEJOURS, C. A banalização da injustiça social. Rio de Janeiro: Fundação Getulio Vargas, 1999.

DEJOURS, C.; ABDOUCHELI, E.; JAYET, C. Psicodinâmica do trabalho: contribuições da escola dejouriana à análise da relação prazer, sofrimento e trabalho. 2. ed. São Paulo: Atlas, 2009.

ENRIQUEZ, E. A organização em análise. Petrópolis: Vozes, 1997.

ENRIQUEZ, E. Vida psíquica e organização. In: MOTTA, F. C. P.; FREITAS, M. E. (Orgs.). Vida psíquica e organização. 2. ed. Rio de Janeiro: FGV, 2002. p. 11-22.

ENRIQUEZ, E. Jogos de poder na empresa: sobre os processos de poder e estrutura organizacional. São Paulo: Zagodoni, 2014.

FEDERAÇÃO BRASILEIRA DE BANCOS - FEBRABAN. Relatório Anual 2016. 2017. Available at: $<$ https://relatorioanual2016.febraban.org. $\mathrm{br} / \mathrm{pt} /$ download/FEBRABAN_RA_16.pdf>. Accessed on: Feb. 06, 2018.

FLAMENT, C. Estrutura e dinâmica das representações sociais. In: JODELET, D. (Org.). As representações sociais. Rio de Janeiro: UERJ, 2001. p. $174-186$.

FREITAS, J. A. S. B. Controladoras estrangeiras e conhecimento organizacional nas controladas brasileiras: estudo de caso nas áreas de varejo de duas organizações bancárias. 2005. Thesis (Doctor Degree in Business Administration) - Pontifícia Universidade Católica do Rio de Janeiro, Rio de Janeiro, 2005.

FREITAS, M. E. Cultura organizacional: identidade, sedução e carisma? 2. ed. Rio de Janeiro: FGV, 2000.

FREITAS, M. E. A questão do imaginário e a fronteira entre a cultura organizacional e a psicanálise. In: MOTTA, F. C. P; FREITAS, M. E. (Orgs.). Vida psíquica e organização. 2. ed. Rio de Janeiro: FGV, 2002.
GAULEJAC, V. A gestão como doença social: ideologia, poder gerencialista e fragmentação social. São Paulo: Ideias e Letras, 2014.

JINKINGS, N. Trabalho e resistência na fonte misteriosa. Campinas: Unicamp, 2002.

JODELET, D. Representações Sociais: um domínio em expansão. In: JODELET, D. (Org.). As representações sociais. Rio de Janeiro: UERJ, 2001. p. 17-44.

JODELET, D. O movimento de retorno do sujeito e a abordagem das representações sociais. Sociedade e Estado, v. 24, n. 3, p. 679712, 2009.

MARKOVÁ, I. The making of the theory of social representations. Cadernos de Pesquisa, v. 47, n. 163, p. 338-374, p. 2017.

MARTINS-SILVA P. O. et al. Teoria das representações sociais nos estudos organizacionais no Brasil: análise bibliométrica de 2001 a 2014. Cadernos EBAPE.BR, Rio de Janeiro, v. 14, n. 4, p. 891-919, 2016.

MÁXIMO, T. A. et al. Exigências nos percursos profissionais dos gerentes de banco. Psicologia e Sociedade, v. 23, n. 1, p. 66-74, 2011.

MORGAN, G. Imagens da organização. 15. reimp. São Paulo: Atlas, 2011.

MOSCOVICl, S. La psychanalyse, son image et son public. Paris: Presses Universitaires de France, 2004. Available at: <http://doi. org/10.3917/puf.mosco.2004.01>. Accessed on: Feb. 06, 2018.

MOSCOVICI, S. Representações sociais: investigações em psicologia social. 11. ed. Petrópolis: Vozes, 2015.

MOTA, K. S. Trabalhar pra quê? Percepções sobre trabalho entre jovens de diferentes estratos sociais. 2012. Thesis (Master Degree in Business Administration) - Fundação Getulio Vargas, São Paulo, 2012.

PAGÈS, M. et al. O poder das organizações. São Paulo: Atlas, 2006.

RESENDE, S.; MENDES, A.M. A sobrevivência como estratégia para suportar o sofrimento no trabalho bancário. Revista Psicologia: Organização e Trabalho, v. 4, n. 1, p. 151-175, 2004.

SALLES, D. M. R.; COSTA, I. S. A. Representações do trabalho: estudo sobre confinamento na indústria petrolífera. RAE, v. 53, n. 3, p. 230242, 2013.

SELIGMANN-SILVA, E. Os riscos da insensibilidade. In: ARAÚJO, A. J. S. et al. (Orgs.). Cenários do trabalho: subjetividade, movimento e enigma. Rio de Janeiro: DP\&A, 2004. p. 51-72.

SILVA, M.C.; COSTA, I.S.A. Sobreviver ao trabalho: narrativas míticas na realidade organizacional. Revista de Administração Unimep, v.13, n. 1, p.141-164, 2015.

SILVA, M. L. E. Interpretação de testes projetivos: projeção e representação. Rio de Janeiro: Campus, 1981.

THIRY-CHERQUES, H. Sobreviver ao trabalho. Rio de Janeiro: FGV, 2004. VAN KOLCK, O. L. Interpretação psicológica de desenhos. 2. ed. São Paulo: Pioneira, 1981.

YIN, R. K. Pesquisa qualitativa do início ao fim. Porto Alegre: Penso, 2016. 
Elena Bandeira da Silva

ORCID: https://orcid.org/0000-0002-9159-1250

Master degree in Administration at Universidade Estácio de Sá (UNESA); Psichologist, Rio de Janeiro - RJ, Brazil. E-mail: elenabandeira@hotmail.com

Isabel de Sá Affonso da Costa

ORCID: https://orcid.org/0000-0002-4386-9385

PhD degree in Administration at Fundação Getulio Vargas (FGV); Adjunct Professor at Universidade Estácio de Sá (MADE/UNESA), Rio de Janeiro - RJ, Brazil. E-mail: isabel.costa@estacio.br

Jorge Augusto de Sá Brito e Freitas

ORCID: https://orcid.org/0000-0002-0371-0409

PhD degree in Business Administration at Pontifícia Universidade Católica do Rio de Janeiro (PUC-Rio); Adjunct Professor at Universidade Estácio de Sá (MADE/UNESA), Rio de Janeiro - RJ, Brazil. E-mail: jasbfreitas@globo.com

Denise Medeiros Ribeiro Salles

ORCID: https://orcid.org/0000-0001-8378-7117

PhD degree in Administration at Fundação Getulio Vargas (FGV); Adjunct Professor at Universidade Federal Fluminense (UFF), Niterói - RJ, Brazil. E-mail: denisesalles@id.uff.br 